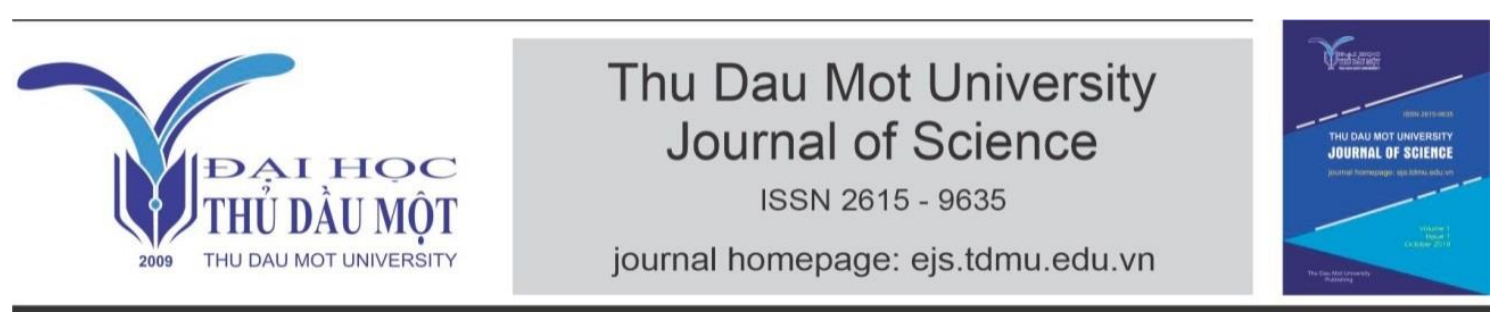

\title{
Applying morphology and contextual communication in learning English vocabulary
}

by Nguyen Van Hung (Thu Dau Mot University)

Article Info: $\quad$ Received 11 Jan. 2021, Accepted 1 Mar. 2021, Available online 15 Mar. 2021

Corresponding author: hungnv.nn@tdmu.edu.vn

https://doi.org/10.37550/tdmu.EJS/2021.01.149

\begin{abstract}
In the trend of globalization and international integration of Vietnam today, learning foreign languages in general and English in particular is aimed at achieving learners' communication purposes. Therefore, learning the language knowledge including vocabulary is also for the purpose of developing learners' communication skills. The non-majored English training for students at the Foreign Language Center - Thu Dau Mot University is directed to the effectiveness of communication. The most prominent method of learning vocabulary is the application of Morphology and Morpheme; At the same time, the method of learning meanings of words in contexts and application of newlylearned words in the practice of communication skills will be also focused.
\end{abstract}

Keywords: learning English vocabulary, morphology, morphemes

\section{Introduction}

In the tendency of globalization, foreign languages play an important role and is the key to the development and international integration of our country in today's era. The experience of developed countries and emerging industrial countries in the world as well as in the Asia-Pacific region has shown that, in the necessary conditions for integration and development, foreign languages are a vital requirement and an effective means in the process of integration and development of each country. 
In order to realize the mission of "training qualified human resources for socio-economic development and international integration of Binh Duong province, the Southeast region - the key economic region of the South" (Resolution, 2018), Thu Dau Mot University focuses on teaching foreign languages to all of its students, especially students not majoring in foreign languages. Of all the foreign languages learned by the university's students, English is chosen by most students due to the high popularity and demand for recruiting human resources who can use this foreign language of enterprises in Binh Duong and in the neighboring provinces as well.

As mentioned above, In the trend of globalization today, learning a foreign language in the era of globalization has become extremely necessary and urgent. Today, learning foreign languages is mainly aimed at meeting people's needs of communicating in their work and daily life as well. Therefore, in the process of teaching and learning English, the practice to develop communication skills is the learner's ultimate goal.

To be able to practice English communication skills such as listening, speaking, reading and writing, learners need to acquire necessary language knowledge as grammar, vocabulary and pronunciation. The language knowledge is indispensable materials that help learners enhance their language skills. One of the important language materials to which learners are required to pay attention in foreign language classes is vocabulary. However, learning vocabulary at elementary schools and high schools has always been so hard for foreign language learners, especially learners of English, because learning words requires a lot of effort in looking up the word's part of speech, meaning and transcription. In addition to getting to know the meaning, the pronunciation of new vocabulary, learners also have to learn the new word many times until they can remember its spelling and the meaning.

\section{Literature review}

\section{Tradiontional ways of learning vocabulary}

In the process of teaching and learning English in all grades at elementary and high schools, teachers focus on teaching vocabulary to students. Nevertheless, the methods of teaching and learning vocabulary at elementary and high schools have been so passive and ineffective in communication. Commonly, students only learn vocabulary in the level of knowing, memorizing, and reproducing. At the beginning of each English Unit, the teacher lists new English words and their equivalent Vietnamese meanings on the board. Students write the new words in their notebooks and then go home copying the new words many times until they remember both spelling and meaning. In the next class, the teacher calls the students to come up to the board, read the Vietnamese 
meanings and ask them to write the English words on the board and give them a score (usually for the oral mark). Due to their young age and good memory, students can learn and remember new words with ease. However, after a short time students will forget the learned vocabulary for not using them in communication and not studying them repeatedly.

Based on the survey of two non-English-majored classes of level 4 and 5 Thu Dau Mot University's Foreign Language Center with a total student population of 67, the majority of students learned English vocabulary by copying to memorize them at primary schools and high schools. Up to 61/67 students surveyed from the above 2 classes, accounting for $91.04 \%$, confirmed that they had copied the list of words and meanings provided by their teachers until they remembered their spellings and meanings. The remaining $8.96 \%$ of students (6/67 students surveyed), when randomly interviewed, said they had studied English at specialized schools or English centers. These students reported they learned vocabulary in contexts and applied them in communication.

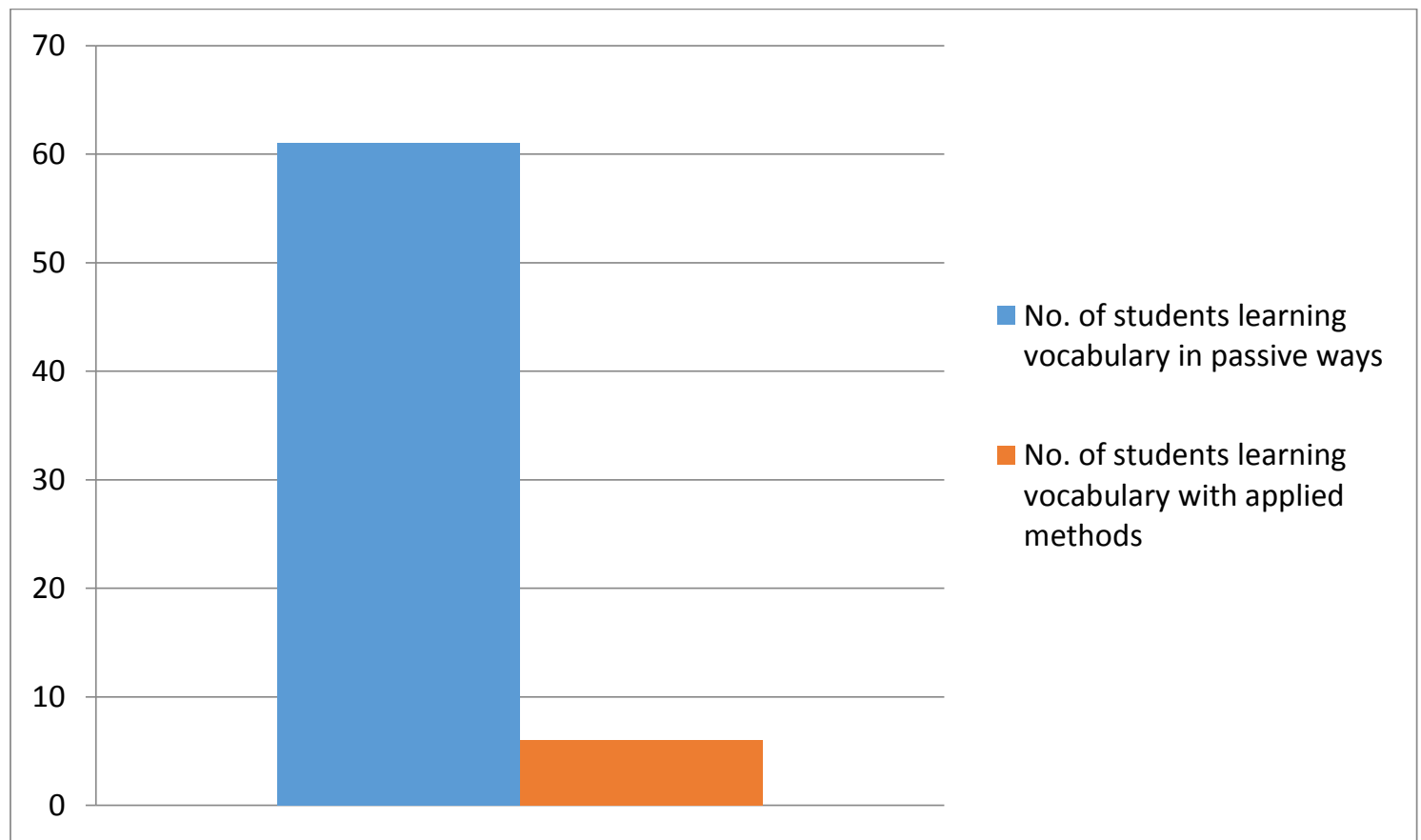

\section{Methods}

This study used quantitative research and qualitative analysis to determine the method which non-English-majored students apply to learn vocabulary. The findings gained by the surveys as a foundation for action plan laid out by the researchers. 


\section{Results and Discussion}

\subsection{Applying morphology and morpheme in learning vocabulary}

In the limited extent of this article, the application of Morphology and Morpheme to form new words (word formation) will be introduced to students of Thu Dau University. Morphology is a branch of Linguistics mentioning to the structure of English vocabulary and how to form new vocabulary by combining Morphemes. Morpheme is the smallest meaningful unit in a word that cannot be divided any more. There are two types of morphemes: (1) free morpheme (core morpheme or independent morpheme), and (2) bound morpheme (dependent morpheme). A free morpheme can stand itself as an independent word. A bound morpheme, however cannot be an independent word. It must be combined with a free morpheme or another bound morpheme. A single word has a free morpheme, but a complex one must have a free morpheme and one or more bound morphemes. Bound morphemes come in three types: prefix, infix and suffix.

For example:

The adjective tranquil is a simple word that has only one free morpheme. On the basis of "tranquil", the bound morpheme -ize (suffix) can be added to create the verb tranquilize; and then the noun tranquilizer is derived by adding the bound morpheme er.

By applying morphemes in learning English vocabulary, students just learn one root word with a free morpheme and create several of its derivations in listening, speaking, reading, and writing activities without looking them up in a dictionary or memorizing them. For example, students who know the word industry (noun) can themselves form industrial (adj.) or industrialize (verb) in case they need to use an adjective or a verb.

Thus, in the process of teaching non-specialized English modules at the Foreign Language Center - Thu Dau Mot University, teachers need to introduce to students some basic principles of morpheme such as free morpheme and bound morpheme. Students, then are able to form new words by adding bound morphemes to the root word. For example, on learning the word rely, students just memorize its spelling, part of speech and the meaning; and in certain communication situations, they can add the suffix -able to establish the adjective reliable or the prefix -un to get the negative adjective unreliable.

Based on the survey of 67 students in two English classes (as mentioned in part II), $82.09 \%$ (54/67) of them found the method of learning words using morphemes is very convenient, less time consuming and no need to learn and memorize many words. These students claim they can use morphemes by themselves to create new words that need to be used in speaking and writing skills without looking them up in a dictionary, and at 
the same time they can easily guess the meaning of the derived words in reading texts or recordings.

The remaining $17.91 \%$ of students (13/67) are not sure of the new words they create. The students reported they could identify derived words from their roots in reading texts and recorded speeches; However, they have to check the words in the dictionary when using them in writing and speaking exercises.

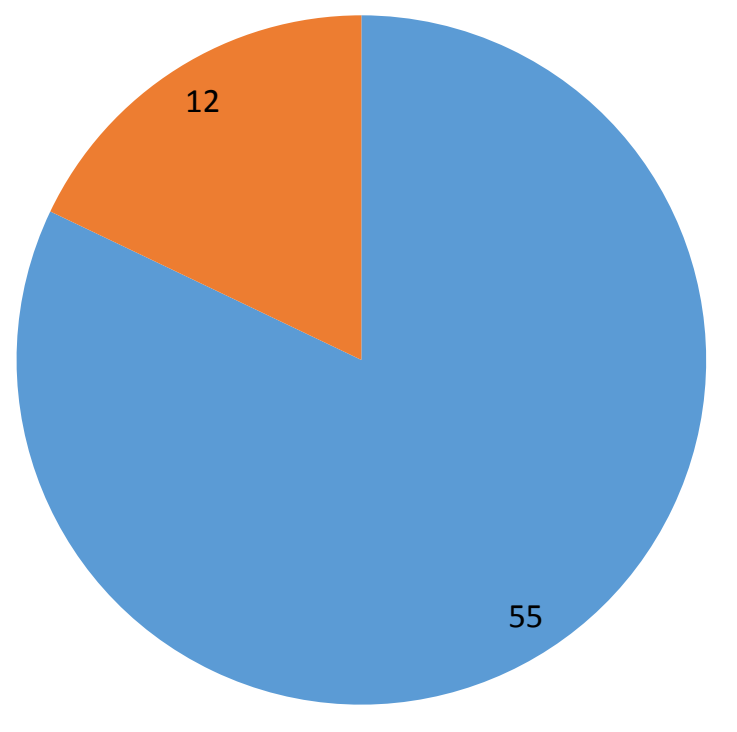

82.09\% students who are satisfied

$17.91 \%$ students who are not self-confident

\subsection{Learning vocabulary in contexts}

The second method of learning vocabulary is learning words in a context. In comparison with the traditional method, learning vocabulary in context is practical. It helps students know how to learn the meaning of new words in a sentence and use learned vocabulary in communicative situations.

\subsection{Learning words in contexts}

In this method, the learner is asked to read the contexts and choose one of the given words to fill in the incomplete sentence. Thanks to this exercise, learners can remember the words and their meanings and know how to use words in a sentence (context) as the in following example:

Complete the following sentences with the words in the box (Enter given words in the blanks of the sentences below). 


\begin{tabular}{|lll|}
\hline $\begin{array}{l}\text { a year off } \\
\text { do a Master's }\end{array}$ & left school & primary school \\
graduated & my finals & second year \\
& nursery & university \\
\hline
\end{tabular}

2. When I was at I wanted to become a doctor, but when I went to secondary school I got bad grades in science.

3. My brother's in his at secondary school.

4. I when I was sixteen because I wasn't interested in studying.

5. I'm taking . I'm working and saving money for my university fees.

6. I'm studying English at because I want to become a teacher.

7. I've got next term. Hopefully, I'll pass.

8. When I , I wanted to get a job in the media, but it was impossible to find one.

9. If I want to get a good job, I'll have to

When reading the first sentence, students manipulate assert to words they have learned as three-year-old daughter, start, go back to work to guess the missing word: nursery.

\subsection{Using new vocabulary in speaking activity}

The method of learning vocabulary in contexts enables students to use new vocabulary in practicing speaking skills. After teaching new vocabulary meaning by method for students to guess the meaning of word in context from a reading text or a dialogue, the teacher allows students to practice speaking using new words learned.

For example, when teaching vocabulary of technologies such as cell phones, the teacher might suggest questions such as "Do you have a cell phone?" (Do you have cell phone?), "How long have you had it (your cell phone)?" (How long do you buy / have it?), "Is it important for you? Why? " (Is it important to you? Why?), "What do you use it for?" (What do you use it for?) ... Students use these posting questions, or create new ones) to practice in pairs. Thanks to this question and answer practice, students can both learn new words, know how to use them in context, and especially practice their English speaking skills right in each activity of each English class.

\section{Conclusion}

Learning English in the trend of globalization and international integration of Vietnam today is mainly aimed at developing learners' communication skills. Therefore, learning English knowledge as vocabulary also serves the purpose of developing students' listening, speaking, reading and writing skills. The training of non-specialized English 
for students at the Center for Foreign Languages - Thu Dau Mot University is aimed at communication proficiency, most notably the method of learning vocabulary through the application of Morphology and Morpheme. At the same time, it also focuses on the method of learning meaning in the context and applying the newly learned vocabulary to practice communication skills.

\section{References}

Jack C Richards; John Talbot Platt; Heidi Platt; C N Candlin (1985), Longman Dictionary of Applied Linguistics, Nxb Longman

Geert Booij (2005), The Grammar of Words - An Introduction to linguistics Morphology, Oxford University Press.

Hugh Dellar; Andrew Walkley (2016), Outcomes - Pre-Intermediate, Nxb National Geographic Learning.

Resolution No. 05/NQ-HĐTr dated 22/06/2018 of Thu Dau Mot University's Board. On approving the development strategy of Thu Dau Mot by 2030. 